\title{
Gender And Diplomacy: Practice and Challenge in Indonesia In the Covid-19 Pandemic Era
}

\author{
Machya Astuti Dewi ${ }^{1}$, Iva Rachmawati ${ }^{2}$ \\ \{machya@upnyk.ac.id ${ }^{1}$, ivarachmawati@upnyk.ac.id²\} \\ Department of International Relations, Faculty of Social and Political Science \\ Universitas Pembangunan Nasional Veteran Yogyakarta
}

\begin{abstract}
Do women make a difference in diplomacy? The question is interesting but neglected in the practice of diplomacy. In handling the COVID19 pandemic, the Minister of Foreign Affairs of Republic Indonesia: Her Excellency Retno Marsudi, proved to be excellent with her initiative and intense eagerness to negotiate vaccine needs for Indonesia. The Ministry of Foreign Affairs of the Republic of Indonesia is also very well known for its reputation in implementing gender equality. This paper used a qualitative method to describe how gendered diplomacy contributes to handling the COVID-19 pandemic and the challenges. The COVID-19 pandemic has gender dimensions that have implications for diplomacy. As a female Minister, an excellent reputation has been achieved in handling COVID-19 that represents the women's and their family's basic needs through health diplomacy or vaccine diplomacy using bilateral and multilateral negotiation with China, Japan, United States, Netherland, and WHO, and COVAX facility. Another crucial issue during the pandemic is the protection of Indonesian citizens abroad. Here the role of female Indonesian diplomats is increasingly needed. Using the characteristics embedded in women: gentle, sensitive, and motherly, the female Indonesian diplomats handle cases during the pandemic. While there is an increasing number of female diplomats in the Indonesian Ministry of Foreign Affairs, two questions still arise: Do the female diplomats represent women's interests, and will their presence decrease the misunderstanding of what gender mainstreaming is.
\end{abstract}

Keywords: Gender; Diplomacy; COVID-19 Pandemic

\section{Introduction}

Scientific research on gender and diplomacy is still rarely found (Aggestam, 2018). Aspects of gender and culture have not been thoroughly studied in the diplomacy literature. Some believe that diplomacy is gender neutral. But feminists argue that gender influences political life. Studies in neo-institutionalist literature clearly analyze how institutions balance between structure and agency, encouraging a better understanding of the co-constitutive nature 
of politics (Rossetti, 2015). Diplomacy is believed to be closely related to gender and exclusion practices and women in a male-dominated world. By using feminist theory in diplomacy we can understand how diplomacy has changed over time in response to gender relations in social shifts. In turn gender reality can be explained by analyzing how diplomatic practices reproduce patriarchal social structures (Standfield, 2020). One example is the Turkish case. While masculine norms persist in diplomacy, they are actually weakening gradually with the increasing number of Turkish female diplomats being promoted to high and prestigious posts (Suleymanoglu-Kurum, 2018).

It is interesting to examine how gender has implications for the practice of Indonesian diplomacy. The Ministry of Foreign Affairs of the Republic of Indonesia is one of the government institutions in Indonesia that has implemented gender mainstreaming since 2015. Currently, the Ministry of Foreign Affairs of the Republic of Indonesia is led by a female minister. The number of female civil servants and female diplomats continues to increase from year to year. Quantitatively, the increasing number of women in the Ministry of Foreign Affairs shows that there are open opportunities for women to enter the world of diplomacy. This also indicates that more and more women are attracted to enter the world which is often identified with male domination.

In responding to the importance of gender equality, Indonesia has aligned its foreign policy with the principles and norms of gender equality. Indonesia focuses on increasing the role of women as peace agents and increasing the number of female UN peacekeepers. To increase the role of women in the peace process, in 2019, Indonesia held a regional training to increase the capacity of female diplomats in analyzing and preventing conflict and building post-conflict peace. Indonesia also held a dialogue on the Role of Women in Building and Sustaining Peace to encourage and increase the role and capacity of Afghan women in the peace process in their country. This activity was followed by the implementation of the Afghanistan-Indonesia Women's Solidarity Network in Kabul, Afghanistan, in 2020. Meanwhile, to increase the role of women in the United Nations (UN) peacekeeping force, Indonesia sent female personnel as military observers to the UN mission in Congo in 2005. Indonesia is also targeting to increase the number of female peacekeepers from $4 \%$ to $7 \%$ (The Conversation, January 5, 2021).

Some researchers suggest that pandemics affect the performance of female diplomats. Gender dynamics due to the corona crisis have implications for the practice of diplomacy. Towns et al (2020) emphasize the importance of paying deep attention to aspects of gender in the study of diplomacy due to crises. As a result of the COVID-19 pandemic there is gender inequality in diplomatic duties. It is associated with a variety of new adaptation habits, lockdown policies and travel restrictions. The daily tasks of moving to online interaction and the practice of consular diplomacy also have gender implications. On the other hand, the impact of the COVID-19 pandemic on the practice of gender inequality outside diplomacy also has a lot of impact on diplomatic work.

The COVID-19 pandemic has many gender effects, such as violence against, lame division of labor in childcare, family health care, and more. This phenomenon, and other COVID-19related changes affect gender aspects of diplomacy practice. For female diplomats working out of office hours in practice is difficult to implement, especially if they already have a family. Female diplomats who have families and have children often have more parental responsibilities than male fellow diplomats. Studies of various professions show inequality between men and women when faced with online work from home. On the one hand video conferencing that replaces real meetings makes the way of dressing and the rules of protocol more flexible. Gender dynamics and inequality can therefore be neutralized, for example by 
reducing the time for physical representation. But online meetings eliminate the opportunity for female diplomats to star in a crowd of male diplomats. The strategy of effacing as a female diplomat is more difficult to implement in online meetings when all participants of the trial are only visible in small pictures that all have the right to speak. The COVID-19 pandemic has awakened international relations researchers to pay more attention to the close relationship between gender and diplomacy. Diplomacy is a foreign policy channel that has a gender dimension, including feminist foreign policy adopted by many countries. Many questions are growing from the gender and diplomacy dimensions, especially related to the COVID pandemic. Among them is how diplomacy and diplomats respond to gender inequality in the world of diplomacy whose situation is further exacerbated by COVID-19? How diplomats interpret and implement foreign policy. Similarly, the question of how different gender dimensions can affect the practice of diplomacy in the COVID pandemic.

The important task of diplomats in carrying out international cooperation during a pandemic is a challenge in itself. Since the pandemic, the focus of Indonesia's diplomacy has been in the medical field, such as diplomacy on vaccines, medical devices and medicines, as well as in non-medical fields such as repatriation or evacuation of Indonesian citizens, protection of Indonesian citizens and dissemination of information. Using assistance and cooperation mechanism with other countries or international organizations, Indonesia has received financial assistance and goods such as Personal Protective Equipment (PPE), masks and test kits. In addition, Indonesia is also trying and collaborating to make a Covid-19 vaccine (Indonesian Ministry of Health, January 20, 2021).

COVID-19 strengthens collaboration that may potentially solidify global solidarity. A pandemic response built on strategic global health diplomacy, vaccine diplomacy, and science diplomacy can spur both political and economic benefits, advancing development, health security, and justice. The virus thrives and flourishes in the face of political divisions and a lack of cooperation. While the current global crisis has exacerbated the existing social injustices in societies, national unity and global solidarity are essential to winning the fight against the COVID-19 pandemic (AlKhaldi et. al, 2021). Lack of international cooperation will increase inequalities between countries and injustice because people in countries that have difficulty obtaining vaccines will be more vulnerable to the effects of pandemics. Although trade cooperation has impacted geopolitical and competitive shifts, governments have an obligation to align trade and health policies. In the midst of the global health crisis the World Health Organization (WHO) is facing a phenomenon of increasing violations of the International Health Regulations (Javed \&Chattu, 2020). The role of diplomacy and international cooperation is very important during the COVID-19 pandemic. Could female diplomats carry out that role? What is the role of Indonesian female diplomats during the pandemic? Has the pandemic weakened or strengthened the role of female diplomats? This paper will analyze the role of female Indonesian diplomats during the COVID-19 pandemic and the challenges faced.

\section{Methodology}

This research uses a qualitative approach. The data was collected from document studies, uploads from the Indonesian Ministry of Foreign Affairs' Official Facebook, the website of the Ministry of Foreign Affairs of the Republic of Indonesia, and online mass media. The documents being tracked are policies or regulations regarding gender mainstreaming in the Indonesian Ministry of Foreign Affairs. Posts from Facebook are a source of data to 
understand the perspective of the Ministry of Foreign Affairs on gender mainstreaming, the views of the foreign minister, as well as netizen comments on gender mainstreaming in the Ministry of Foreign Affairs. The official Facebook of the Ministry of Foreign Affairs is @ Kemlu.RI with the link https://www.facebook.com/Kemlu.RI/.

Meanwhile, the official website of the Indonesian Ministry of Foreign Affairs can be found at https://kemlu.go.id/portal/id. This website is used to track the activities of the Ministry of Foreign Affairs and the statements of officials at the Ministry of Foreign Affairs. Several online mass media, namely Liputan6, Antaranews.com, Berita Satu, and CNBC Indonesia are sources for obtaining data on the statements of the Minister of Foreign Affairs, Ministry of Foreign Affairs Officials and Female Diplomats. The feminist perspective is used in this study by paying attention more to the experiences of women with their respective backgrounds. The data was categorised, interpreted, and analyzed using descriptive qualitative data. Following the problems studied, the final result of the study is a description of the roles and experiences of Indonesian female diplomats during the COVID-19 pandemic and the challenges faced.

\section{Result and Discussion}

\subsection{Gender Mainstreaming in the Ministry of Foreign Affairs}

In 2000, under President Abdurrahman Wahid, the Indonesian government issued Presidential Instruction Number 9/2000 about Gender Mainstreaming in National Development. The Minister of Foreign Affairs of the Republic of Indonesia Retno Marsudi followed up 15 years later by signing a Memorandum of Understanding with the Minister of Women's Empowerment and Child Protection on the Implementation of Gender Mainstreaming in the Protection of Women and Children in the Ministry of Foreign Affairs (Indonesian Ministry of Foreign Affairs, March 10, 2015). In 2020, the Indonesian Minister of Foreign Affairs issued Regulation of the Minister of Foreign Affairs of the Republic of Indonesia Number 21 of 2020 concerning Guidelines for the Implementation of Gender Mainstreaming in the Ministry of Foreign Affairs. In this Ministerial Regulation, it is stated that the Ministry of Foreign Affairs will formulate a gender integration strategy implemented through planning, implementation, budgeting, monitoring, and evaluation of policies, programs, and activities in foreign relations. The aim is to ensure the achievement of gender justice and equality. Gender mainstreaming should be supported by gender-responsive budgeting (https://jdih.kemlu.go.id).

The Minister of Foreign Affairs stated that women's issues were mainstreamed in the Ministry of Foreign Affairs during her tenure. In recent recruitments at the Ministry of Foreign Affairs, more than half of the diplomats were women. Seven of the ten highestranking diplomats are occupied by women. In 2020 the number of female civil servants in the Indonesian Ministry of Foreign Affairs will be $64 \%$ of the total employees. As many as $38 \%$ of them are female diplomats diplomats (Indonesian Ministry of Foreign Affairs, July 14, 2018). Women play an important role in Indonesia's diplomacy. Women's issues have been at the forefront of Indonesia's foreign policy in the last six years. Some examples of concrete tasks being carried out are taking care of Rohingya female refugees in Bangladesh. Another example is helping female refugees in Palestine by providing capacity building on economic independence (Tribunnews.com, April 22, 2021).

In 2019, along with Indonesia's position as president of the UN Security Council, Indonesia promoted the role of women in the World Peacekeeping Mission. For Indonesia 
women play an important role in conflict prevention, conflict management, and post-conflict peacebuilding. In countries that are in conflict GBV (gender-based violence / GBV) and conflict-related sexual violence (ConflictRelated SexualViolence / CRSV) often occurs. As both civilians and fighters, women and children are the most common victims in the conflict. Female family members of combatants are often subjected to sexual violence and abuse. This is a barrier for women to move freely. In conflict areas that receive humanitarian aid, women and girls are often forced to pay sexual rewards for obtaining such humanitarian aid. Here women peacekeepers play an important role in addressing problems related to GBV and CRSV in conflict areas. Indonesia believes that the presence of women as peacekeepers will contribute greatly to the success of the mission, because women have an important role in the social construction of society and have psycho-social aspects that make women have 'privileges' in humanitarian missions. Women are also considered more sensitive to the local environmental and cultural context, thus facilitating public acceptance of the existence of female peacekeepers. The presence of female peacekeepers provides a sense of security and comfort, especially for children and women who are often victims of sexual violence in conflicts. Female peacekeepers also serve as early peace initiators and role models for local women in encouraging peace-building activities, including those related to security aspects such as ceasefire, demobilization, and reintegration processes, as well as negotiations (Indonesian Ministry of Foreign Affairs, May 29, 2019). Therefore, female peacekeepers are considered to have advantages and added values. Indonesia's foreign minister stated: "They can be more easily accepted and trusted in helping the community of women and children. As a woman, I am very proud... The number of Indonesian female peacekeepers continues to rise... It's an incredible plus... The world's largest Muslim country is sending female peacekeepers to the UN peacekeeping mission" (Indonesian Foreign Ministry, February 28, 2018).

Indonesia has sent peacekeepers since 1957. In 2019 Indonesia was in 8th position out of 124 countries that contributed the largest personnel with 3,080 personnel, 86 of whom were women (female peacekeepers). They are spread across 8 UN Peacekeeping missions, namely in UNIFIL $($ Lebanon $)=45$, MINUSCA $($ Central Africa $)=2$, UNAMID $($ Darfur, Sudan $)=7$, MONUSCO (Democratic Republic of Congo) $=28$ and UNMISS (South Sudan) $=4$ (Ministry of Foreign Affairs of the Republic of Indonesia, 21 April 2019). The number of women personel increases to 157 in 2020 (Berita Satu, October 16, 2020). When Indonesia became President of the United Nations Security Council in August 2020, Indonesia succeeded in issuing a UN Security Council Resolution that empowered female peacekeepers, as well as provided protection for them (Tribunnews, 22 April 2021). The importance of women in world peace is highly emphasized by the Ministry of Foreign Affairs. In a Facebook post on March 8 2019, coinciding with World Women's Day, the Ministry of Foreign Affairs wrote: "Today, March 8, is celebrated as International Women's Day. For women all over the world, this is 'your day', let's together be tough women who contribute to world peace" (Indonesian Ministry of Foreign Affairs, 8 March 2019). In an upload on May 29, 2019, the Ministry of Foreign Affairs stated: "Indonesia hopes that the role of women in peace and security is not supposed to be extraordinary, but the norm, because "investing in women, equals investing in peace" (Indonesian Ministry of Foreign Affairs, May 29, 2019).

An official at the Indonesian Ministry of Foreign Affairs noted that the Indonesian Ministry of Foreign Affairs had successfully implemented gender equality. There are two parameters that she sees, and the first is the Ministry of Foreign Affairs institution. First, the Indonesian Ministry of Foreign Affairs has improved its institutions so that the mechanisms 
and systems are gender-responsive. The second is gender mainstreaming in the implementation of Foreign Policy. The Indonesian Ministry of Foreign Affairs provides equal opportunities and equal access to men and women:

"Don't be marginalized. The institution now has a gender mainstreaming working group. All implemented. Bilateral and multilateral units will apply. For example, we can help bilateral gender mainstreaming in Afghanistan. There is training for genderresponsive elections. In multilateral we are also champions in Peace Keeping Operation (PKO). We are one of the contributors to the spread of the PKO soldier. We care for women to be safe" (Podcast interview with Siti Mauludiah, April 21, 2021).

Various groups conveyed many positive responses towards the pro-gender equality policies carried out by the Indonesian Ministry of Foreign Affairs, both from internal employees of the Ministry of Foreign Affairs and the community. The following table is an excerpt of positive comments about gender equality policies at the Ministry of Foreign Affairs uploaded by netizens.

Table 1. Netizens Comments on Gender Equality at the Ministry of Foreign Affairs of the Republic of Indonesia

\begin{tabular}{|c|c|c|c|}
\hline No & Content & Date & Account Name \\
\hline 1 & $\begin{array}{l}\text { Pro-gender policies at the Ministry of Foreign Affairs } \\
\text { currently husband and wife diplomats may be placed in } \\
\text { the same country but not one building - Minister of } \\
\text { Foreign Affairs Retno Marsudi }\end{array}$ & $\begin{array}{l}\text { March 29, } \\
2016\end{array}$ & @petz09 \\
\hline 2 & $\begin{array}{l}\text { @ kemenluRI } \\
\text { Retno Marsudi Agent of change for gender equality and } \\
\text { women's empowerment. }\end{array}$ & $\begin{array}{c}\text { February } 14 \\
2018\end{array}$ & @Almagha \\
\hline 3 & $\begin{array}{l}\text { Diplomats@Kemlu_RI need to deepen their knowledge } \\
\text { of gender mainstreaming \& gender equality norms to } \\
\text { realize the implementation of gender-sensitive foreign } \\
\text { policies \& work environment policies, including through } \\
\text { education levels } \\
\text { @KemluPusdiklat@sesdiluenamdua\#sesdilu62 }\end{array}$ & $\begin{array}{c}\text { November } 25, \\
2018\end{array}$ & @naramasista \\
\hline 4 & $\begin{array}{l}\text { Indonesian Embassy in Kuwait in commemoration of the } \\
\text { 25th anniversary of the Beijing Declaration: } \\
\text { Indonesia supports gender mainstreaming } \\
\text { because women are also an important part of } \\
\text { development. }\end{array}$ & $\begin{array}{l}\text { September } 25 \text {, } \\
2020\end{array}$ & $\begin{array}{c}\text { (a) IndonesiaInK } \\
\text { WT, }\end{array}$ \\
\hline 5 & $\begin{array}{l}\text { The Indonesian Ministry of Foreign Affairs led by the } \\
\text { first female Foreign Minister, Minister of Foreign Affairs } \\
\text { Retno Marsudi and with a composition of male and } \\
\text { female diplomats which is almost } 50: 50 \text { makes gender } \\
\text { equality a necessity (\#IWD2021) }\end{array}$ & $\begin{array}{l}\text { March 8, } \\
2021\end{array}$ & @TFaizasyah \\
\hline 6 & $\begin{array}{l}\text { In his key speech, \# Foreign Minister Retno emphasized } \\
\text { the } 3 \text { main things needed to ensure the involvement of } \\
\text { women in the peace process, namely; political support } \\
\text { from the highest levels, technical support and expertise }\end{array}$ & $\begin{array}{l}\text { June } 23, \\
2021\end{array}$ & @indonesiainvc \\
\hline 7 & $\begin{array}{l}\text { Achieving gender equality \& empowering women \& girls } \\
\text { is an unfinished business in our time. So, we roll up our } \\
\text { sleeves and start doing the real work, together. Thank you } \\
\text { to the Ambassadors, } \\
\text { @Kemlu_RI } \\
\text { for the great support! }\end{array}$ & & $\begin{array}{c}\text { @ valeriejullian } \\
\mathrm{d}\end{array}$ \\
\hline
\end{tabular}


Source: Processed from the Official Facebook of the Indonesian Ministry of Foreign Affairs @Kemlu.RI https://www.facebook.com/Kemlu.RI/ The

Comments from various groups indicate appreciation to the Indonesian Ministry of Foreign Affairs and the Minister of Foreign Affairs for achieving the equality program gender that has been implemented. But what about the experience of female diplomats in carrying out their duties? Especially when facing the COVID-19 pandemic and the challenges faced in the world of diplomacy.

\subsection{The Pandemic Challenge}

Since the COVID-19 pandemic, the focus of Indonesia's diplomacy has been adjusted, namely the handling of COVID-19 and the protection of Indonesian citizens abroad. In the early days of the pandemic, the Indonesian Foreign Minister, Retno Marsudi, together with 8 Women Foreign Ministers from various countries held a virtual 'Women Foreign Ministers' Meeting 2020" which discussed the impact of the COVID-19 pandemic on women. The female foreign ministers who participated in the virtual meeting were Marise Payne (Australia), Alexandra Hill Tinoco (El Salvador), Kamina Johnson-Smith (Jamaica), Raychelle Omamo (Kenya), Claudia Blum (Colombia), Kang Kyung-Wha ( South Korea), Maria Arancha Gonzalez Laya (Spain) and Ann Linde (Sweden).On this occasion, Foreign Minister Retno underlined that although women are more vulnerable to being exposed to the negative impacts of the pandemic, women continue to appear at the front, being part of the solution and spearheading the economic and social resilience of the community during a pandemic. The strategic role of women has become increasingly significant amid various policies to work from home or stay at home (Indonesian Ministry of Foreign Affairs, April 17, 2020).

According to the Ministry of Foreign Affairs, there are two steps to increasing the role of women during the pandemic. In the short term, women need to play a more significant role in overcoming vaccine hesitancy and fatigue community against COVID-19. Women's voices must be heard, and they must be included in decision-making. In the long term, women's empowerment must be a priority to recover from the pandemic. Women empowerment can be done by increasing the participation of women in the economy, improving access to digital technology, increasing public awareness of gender equality issues, and creating an enabling environment for equal opportunities for women. Indonesia is committed to advancing the women's agenda, including in the Indonesian Presidency at the G-20. Indonesia takes advantage of this momentum to build a post-pandemic world that is sustainable, resilient, just, and inclusive (https://kemlu.go.id, June 22, 2021).

Foreign Minister Retno Marsudi emphasized that women play an essential role in overcoming the pandemic and promoting recovery. The proportion of global health workers, the majority of whom are women, and the role of women in managing Small and Micro Medium Enterprises to meet medical equipment needs. The statement was delivered in a keynote speech at the High-Level Digital Summit with the theme "Building Forward: Women Political Leaders Determining the New Normal," organized by the Women Political Leaders Network in Brussels, Belgium, on June 21, 2021. Minister Retno stated: "Women are now leading a global campaign to promote equal access to vaccines because all vaccine distribution co-chairs worldwide (COVAX AMC Engagement Group) is a woman. Therefore, women must be the main concern in efforts to recover from the pandemic." (Tribunnews, April 22, 2021). 
Minister Retno's struggle to secure the availability of a COVID-19 vaccine for Indonesia has been extraordinary. Diplomacy carried out by the Ministry of Foreign Affairs of the Republic of Indonesia is one of the keys to handling the pandemic in Indonesia. Since the beginning of the 2020 pandemic, Minister Retno and several ministers in the Working Cabinet have participated in securing the supply of the Covid-19 vaccine. The supply does not only come from commercial channels but also bilateral and multilateral diplomatic mechanisms via COVAX. As of July 2021, Indonesia already has 132,727,140 doses of vaccines consisting of 118 million Sinovac, 8,228,400 AstraZeneca from COVAX, 2 million Sinopharm, then almost 1 million AstraZeneca from Japan and will come again 1 million and the last Moderna from the US as many as approximately 3 million via the COVAX channel (CNBC Indonesia, July $15,2021)$. The effort was not without challenges because there are situations where other countries are fighting over the supply of vaccines. There is also a difficult situation when India, which is the center of pharmaceuticals, suddenly experiences a spike in cases, so that the government prohibits the export of vaccines. As a result, the supply of vaccines throughout the world has been delayed. To overcome this, Minister Retno has discussed dose sharing. Countries that have more vaccines than needed share the excess through the COVAX route.

Another crucial diplomatic issue during the pandemic is the protection of Indonesian citizens abroad. Here the role of female diplomats is increasingly needed. Siti Nugraha Mauludiah Coordinator of the Gender Mainstreaming Working Group at the Ministry of Foreign Affairs of the Republic of Indonesia stated that with the high number of women Indonesians who migrate abroad the role of female diplomats is necessary. To that end, the Ministry of Foreign Affairs has and will continue to place female diplomats in countries where the issue of protection is a special priority. Protection diplomacy has not stopped because of the pandemic and is more relevant than ever: "The effect of gender equality is certainly in the protection effort. Where, the protection of the citizen involves many female diplomats in central and Indonesian representatives, and also the number of Indonesian women who migrated abroad is relatively higher than that of men. "(Liputan6, August 25, 2021).

The Indonesian Ambassador to Italy, Esti Andayani, admitted that she did not experience significant obstacles in her assignment abroad as a female diplomat. However, the experience of handling Indonesian citizens (WNI) during the COVID-19 pandemic has become a challenge. Efforts to monitor and find information about Indonesian citizens exposed to the COVID-19 pandemic are constrained by the health system in Italy which is very careful about patient privacy: "In Italy (conditions) there was a tsunami, the health workers were all busy, they had a hotline, but often they didn't. picked up. What's great is that we can send texts or emails, there are some and then answered. However, usually, if we ask in detail, they will say it is privacy" (rri.co.id, September 8, 2021). During the COVID-19 pandemic, Esti has also succeeded in repatriating and facilitating the needs of Indonesian crew members trapped in Italy. In the process of repatriating Indonesian crew members (ABK), the embassy continues to coordinate with ship companies, both in Italy and Switzerland, as well as with agents for crew members in Indonesia. She used her connections in Italy to assist in the repatriation process for Indonesian citizens. There are 10 cruise ships with a total of 953 Indonesian crew members (Berita Satu, April 22, 2020).

Another experience was told by Esther Rajaguguk who served as the Coordinator of the Consular Function of the Indonesian Consulate General (KJRI) Penang Malaysia. Esther said, especially during a pandemic, what diplomats and staff of the Indonesian Consulate General in Penang had to do was to ensure that their health was in good condition; "The special challenge we face during the pandemic is how to maintain our health, amid our efforts to provide the 
best service in protecting Indonesian Migrant Workers in all of our work areas." Esther explained that the pandemic, which was followed by the implementation of the lockdown in Malaysia, had caused many Indonesian Migrant Workers to lose their jobs and had an impact on their health conditions: "Currently the number of Indonesian citizens who fall ill is either mild illness or in the form of kidney cancer, diabetes, and others, increase. They have gone through various associations or our hotline, asking for assistance in repatriation," (rri.co.id, September 8, 2021).

In 2020 the Indonesian Ministry of Foreign Affairs and Indonesian Representatives abroad had successfully repatriated more than 172,000 Indonesian citizens affected by the pandemic. The settlement of cases for Indonesian citizens has increased compared to the previous year. Among others, it fulfills financial rights to legal assistance for Indonesian citizens who are threatened with the death penalty. The Ministry of Foreign Affairs moves to support national resilience and independence in the health aspect. Specifically for vaccines, the Ministry of Foreign Affairs cooperates both bilaterally and multilaterally to secure the availability of vaccines for the people of Indonesia and the world. (https://m.facebook.com/Kemlu.RI/photos/a.425190977517347/4708766432493092/?type=3 \&source $=48$ ). The success of efforts to protect Indonesian citizens cannot be separated from the role of female diplomats serving in various countries. This shows that female diplomats have abilities that are not inferior to male diplomats.

Male diplomats also expressed positive comments on the performance of female diplomats. Director-General of International Law and Treaties (HPI) Damos Agusman said that female diplomats have advantages: "The female diplomat is very detailed, she knows various angles, such as norms, then what to fight for. The nature of female diplomats in HPI is always prominent in favour of the rights of vulnerable groups." (Liputan6, August 25, 2021).

However, personally, female diplomats have more severe challenges than male diplomats. According to Minister Retno, female diplomats have to combine family and work. Diplomatic work has no boundaries of time, place, and even national borders. Cooperation with a partner is critical for female diplomats to balance work and personal life. Minister Retno said: "In addition to working, we must also take care of children and families, this must be discussed with the husband from the start." However, according to Minister Retno, female diplomats have an advantage in soft power diplomacy, using a dialogue and negotiation approach to resolve problems. "Women have advantages in soft power diplomacy and this is what I have been trying to capitalize on in carrying out my duties as Foreign Minister." (Antaranews.com, October 14, 2019).

Siti Mauludiah said the same thing. According to her, with gentleness on the one hand and strength, on the other hand, female diplomats can play a role. She told how she used her figure as a mother to approach the Indonesian people and citizens while serving in Poland:

While in Poland there were activities with the diaspora and Dharma Wanita (organization of the wife of Indonesia civil servant). I like that they just chat, sit down, listen to input, and then we work on it together. I prefer to provide a channel for discussion. We look for doable for us to do. I feel like a mother figure. I feel a part of them. Closeness as a mother is more effective in embracing the community, embracing young people. I learned from other ambassadors how to approach the community. A year ago in Poland, there was a pandemic. So my role is to do with virtual weekly chat. How do they complain (Siti Nugraha Maulidiyah, podcast interview, April 21, 2021).

However, some people do not agree with the use of soft power diplomacy. As stated by the Indonesian Ulema Council (MUI), the voice of Indonesian diplomacy is not loud. It is time for Indonesia to try to speak louder like Turkey, to perform with megaphone diplomacy, not only 
constructive diplomacy or combine between the two so that the existence of Indonesia is known by the international community (Liputan6, January 23, 2020). This opinion is certainly a challenge for the nature of Indonesia's diplomacy, especially with the leadership style of a female minister.

Another question that arises is whether the increasing number of female diplomats in the Ministry of Foreign Affairs is correlated with a decrease in cases of gender injustice or violence against women experienced by migrant workers. Some Indonesian women activists highlight that the success of the Indonesian Ministry of Foreign Affairs is only at the stage of increasing the number of women in this institution. Currently, the number of employees in the Ministry of Foreign Affairs is almost equal between men and women. Likewise, the increasing number of female diplomats in this Institute. But does the number represent women's gender interests? Will cases of gender injustice automatically decrease in line with the increasing number of women in the Indonesian Ministry of Foreign Affairs? Firliana Purwanti Secretary of the Central Executive Board of the Democratic Party once questioned this: "I highlight the performance of the Minister of Foreign Affairs, Retno Marsudi, on the death penalty policy that is not gender equality friendly," (@MataNajwa,·November 7, 2018).

Another challenge facing the Ministry of Foreign Affairs is the misunderstanding of gender mainstreaming in diplomacy. Gender mainstreaming is often understood narrowly as a program for women. This happened in several activities at the representative office of the Republic of Indonesia. For example, the activities carried out at the Indonesian Embassy in Abu Dhabi, namely English language training and make-up for female workers who live in shelters. There are also Arabic Language Training activities for Dharma Wanita of the Indonesian Embassy in Abu Dhabi. Another example of the narrow understanding of gender mainstreaming is the activity at the Indonesian Embassy in Marseille, which involved Indonesian women in displaying skills in trade and culinary activities at the Indonesian bazaar at the Indonesian Consulate General in Marseille.

\section{Conclusion}

Indonesian women have played a significant role in Indonesia's diplomacy during the COVID-19 pandemic. The current Minister of Foreign Affairs of Indonesia is an extraordinary woman who is persistent in conducting health diplomacy to provide vaccines for the people of Indonesia. Similarly, other female diplomats carry out their duties well to protect Indonesian citizens abroad. Their experience shows that the qualifications of female Indonesian diplomats in the world of diplomacy are identical to those of men. In the pandemic era, they also played their role well, although many adjustments had to be made.

The majority of female Indonesian diplomats stated that characteristics identical with women: gentle, sensitive, and motherly being the strength of female diplomats in carrying out diplomatic tasks, especially during the pandemic. This is interesting because, in a world with male domination, women's characteristics are seen as strengths. Is this the hallmark of female Indonesian diplomats, female diplomats from the "East," or is it the general type of female diplomats worldwide? Whatever the label, the achievements of female Indonesian diplomats still have to be accompanied by strengthening their understanding of what gender equality is in the world of diplomacy.

\section{References}


[1] Antaranews.com. 14 Oktober 2019. Retno Marsudi Sebut Tantangan Diplomat Perempuan Lebih Banyak. https://www.antaranews.com/berita/1111884/retno-marsudisebut-tantangan-diplomat-perempuan-lebih-banyak

[2] Aggestam, K., Towns, A. 2018. The Gender Turn in Diplomacy: A New Research Agenda. International Feminist Journal of Politics Volume 21, Issue 1, 1 January 2019, 9-28.

[3] Berita Satu. 22 April 2020. Diplomasi Kartini Indonesia di Tengah Pandemi Global. https://www.beritasatu.com/politik/623835/diplomasi-kartini-indonesia-di-tengahpandemi-global

[4] Berita Satu. October 16, 2020. "RI Pertahankan Posisi 10 Besar Penyumbang Misi Perdamaian PBB”. https://www.beritasatu.com/nasional/688025/ri-pertahankan-posisi10-besar-penyumbang-misi-perdamaian-pbb ).

[5] CNBC Indonesia. 15 Juli 2021. Menlu Retno Buka-Bukaan Soal Diplomasi Vaksin di Era Pandemi. https://www.cnbcindonesia.com/profil/20210715141003-41261167/menlu-retno-buka-bukaan-soal-diplomasi-vaksin-di-era-pandemi

[6] Menlu RI: Peran Perempuan Penting dalam Tangani Pandemi https://kemlu.go.id, June 22, 2021

[7] Kementerian Luar Negeri RI. @Kemlu.RI. $14 \quad$ Juli 2018. https://www.facebook.com/Kemlu.RI/posts/2366709823365443 10 Maret 2015.

[8] Kementerian Luar Negeri RI. @ @Kemlu.RI. 10 Maret 2015

[9] Kementerian Luar Negeri RI. @Kemlu.RI. 21 April 2019. https:/www.facebook.com/Kemlu.RI/videos/1022073267982806

[10] Kementerian Luar Negeri RI. @Kemlu.RI. 8 Maret 2019. https://www.facebook.com/Kemlu.RI/photos/a.425190977517347/2697893683580387

[11] Kementerian Luar Negeri RI. @Kemlu.RI. $28 \quad$ Februari 2018. https://www.facebook.com/Kemlu.RI/photos/a.425190977517347/2176070769096017

[12] Kementerian Luar Negeri RI. 29 Mei 2019. Peran Krusial Penjaga Perdamaian Perempuan, Sebagai Agen Perdamaian, Toleransi, dan Kemakmuran. https://kemlu.go.id/portal/id/read/343/berita/the-crucial-role-of-women-as-agents-ofpeace-tolerance-andprosperity?fbclid=IwAR0zRI57pCgqzx5GKrdx3c4zqrwBi_6mPfxL3jTcaPLm3cGtyNcbxkNGtM

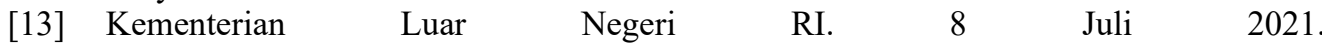
https://m.facebook.com/Kemlu.RI/photos/a.425190977517347/4708766432493092/?ty pe $=3 \&$ source $=48$

[14] Kementerian Luar Negeri RI. 17 April 2020. Ini Diplomasi. Menlu RI pada Pertemuan Para Menlu Perempuan Dunia: Perempuan Adalah Ujung Tombak Atasi Pandemi Covid-19. https://kemlu.go.id/portal/i/read/1213/berita/menlu-ri-pada-pertemuan-paramenlu-perempuan-dunia-perempuan-adalah-ujung-tombak-atasi-pandemi-covid-19

[15] Kementerian Luar Negeri RI. Diplomasi Talk Episode 1: Diplomasi \& Wanita. Wawancara podcast dengan Siti Mauludiah, 21 April 2021.

[16] https://www.facebook.com/watch/?v=455745138841487 
[17] Kementerian Kesehatan RI. 20 Januari 2021. Atasi Pandemi COVID-19 Perlu Kemampuan Diplomasi Global. https://sehatnegeriku.kemkes.go.id/baca/umum/20200922/1235001/atasipandemi-covid-19-perlu-kemampuan-diplomasi-global/

[18] Liputan 6. 23 Januari 2020. MUI Kritik Diplomasi Indonesia Tidak Ada Suaranya. https://www.liputan6.com/global/read/4162694/mui-kritik-diplomasi-indonesia-tidakada-suaranya

[19] Liputan6. 25 Agustus 2021. Pentingnya Peran Perempuan Dalam Diplomasi Perlindungan WNI di Luar Negeri. https:/www.liputan6.com/global/read/4640814/pentingnya-peran-perempuan-dalamdiplomasi-perlindungan-wni-di-luar-negeri

[20] rri.co.id. 8 September 2021. Diplomat Perempuan Cerita Pengalaman Hingga Stigma Indonesia. https://rri.co.id/internasional/1165040/diplomat-perempuan-ceritapengalaman-hingga-stigma-indonesia

[21] Rossetti, Sonia. 2015. Changes for diplomacy under the lens of feminist neoinstitutional theory: the case of Australia. The Hague Journal of Diplomacy 10 (3) 285 305. https://doi.org/10.1163/1871191X-12341314

[22] Standfield, Catriona. 2020. Gendering the practice turn in diplomacy. European Journal of International Relations. Vol. 26(S1) $140-165$ DOI: $10.1177 / 1354066120940351$

[23] Suleymanoglu-Kurum, Rahime, Bahar Rumelili. 2018. Women and Hegemonic Masculinity in Diplomacy: Changing Norms and Practices. Volume: 15, Issue: 57 318.

[24] The Coversation. 5 Januari 2021. Kebijakan pro kesetaraan gender Indonesia: maju di luar negeri, mundur di dalam negeri. https://theconversation.com/kebijakan-prokesetaraan-gender-indonesia-maju-di-luar-negeri-mundur-di-dalam-negeri-150841

[25] Towns, Ann E., Katarzyna Jezierska, Anne-Kathrin Kreft, Birgitta Niklasson. 2020. COVID-19 and Gender: A Necessary Connection in Diplomatic Studies. The Hague $\begin{array}{lllll}\text { Journal of } & \text { Diplomacy } & 15 & \text { (2020) }\end{array}$ http://urn.kb.se/resolve?urn=urn:nbn:se:hv:diva-16033

[26] Tribunnews. 22 April 2021. Retno Marsudi: 64 persen PNS Kemlu RI Tahun 2020 adalah Perempuan. https:/www.tribunnews.com/nasional/2021/04/22/retno-marsudi64-persen-pns-kemlu-ri-tahun-2020-adalah-perempuan?page=2 